СОЦІОКОМУНІКАТИВНИЙ ПІДХІД: МЕТОДОЛОГІЧНІ ВИМІРИ ТА РЕАЛІЗАЦІЯ В СУЧАСНИХ ОСВІТНІХ ПРАКТИКАХ

\author{
SOCIAL AND COMMUNICATIVE APPROACH: \\ METHODOLOGICAL PRINCIPLES AND IMPLEMENTATION \\ IN MODERN EDUCATIONAL PRACTICES
}

УДК 316.74:37

DOI https://doi.org/10.32843/2663-

5208.2020.13-1.13

\section{Мачуліна I.I.}

к.соціол.н., доцент кафредри соціології Дніпровський державний технічний університет

\begin{abstract}
Стаття присвячена аналізу соціокомунікативного підходу у вивченні освіти та його можливостей у формуванні сучасного фрахівця. Соціокомунікативний підхід пояснює механізм трансляції накопиченого досвіду як в історичному, так і в освітньому прочесі. Водночас мета статmі полягає в аналізі соціокомунікативного підходу як методологічної основи у вивченні освіти та можливостей його реалізації в сучасних освітніх практиках. Автором розглянуті основні теоретичні аспекти цього підходу через поняття «код», «кодування», «соціокод», «формальна педагогіка», «неформальнапедагогіка». В контексті соціокомунікативного підходу прочес кодування в освіті розглядається як необхідність забезпечення «символічного порядку», надання форми, тобто те, що можна назвати певною межею в освіті. Водночас поняття «соціокод» є внутрішнім кодом індивіда, його реакчією у відповідь на кодування ззовні, тобто тим, що сорормувала система освіти для окремої особистості. Формування соціокоду відбувається під впливом фрормальної (видимоі) і неформальної (невидимоі) педагогіки. Так, формальна педагогіка (видима педагогіка) - че дотримання в освітньому процесі певних фрормальностей, тобто реалізація освітнього прочесу через освітні програми, навчальні плани тощо. Неформальна педагогіка (невидима педагогіка) - прихована навчальна програма, яка реалізується завдяки впливу соціокультурного освітнього середовища на особистість. Це і участь у наукових гуртках, конфреренціях, олімпіадах, культурно-дозвіллєвих заходах, і спілкування з одногрупниками, викладацьким складом тощо. Отже, в иій статmі доведена необхінність практичного застосування та поєднання принципів формальної (видимоі) та неформальної (невидимоі) педагогіки у фрормуванні сучасного фрахівця через освітні практики.

Ключові слова: соціокомунікативний підхід, формальна педагогіка, неформальна педагогіка, код, соціокод.
\end{abstract}

The article is devoted to the analysis of the social and communicative approach in the study of education and its possibilities in the formation of a modern specialist. The social and communicative approach explains the transfer mechanism of accumulated experience, both in the historical and in the educational processes. However, the purpose of this article is to analyze the social and communicative approach as a methodological basis in the study of education and the possibilities of its implementation in modern educational practices. The author considers the main theoretical aspects of this approach through the concepts of "code", "coding", "sociocode", "formal pedagogy", "informal pedagogy". In the context of the social and communicative approach, the process of coding in education is seen as the need to ensure a "symbolic order", to give form, i.e. what can be called a certain limit in education. At the same time, the concept of "sociocode" is the internal code of the individual, his or her reaction to the coding from the outside, that is, what formed the education system for the individual. The formation of the sociocode is under the influence of formal (visible) and informal (invisible) pedagogy. Thus, formal pedagogy (visible pedagogy) is the observance of certain formalities in the educational process, i.e. the implementation of the educational process through educational programs, curricula and so on. Informal pedagogy (invisible pedagogy) is a hidden curriculum that is realized due to the influence of social and cultural educational environment on the individual. This includes participation in scientific circles, conferences, competitions, cultural and leisure events, and communication with classmates, teaching staff and so on. Thus, this article proves the need for practical application and combination of the principles of formal (visible) and informal (invisible) pedagogy in the formation of a modern specialist with the help of educational practices.

Key words: social and communicative approach, formal pedagogy, informal pedagogy, code, sociocode.
Постановка проблеми. Сучасні тенденції розвитку інформаційної цивілізації пред'являють нові, більш високі вимоги до ролі освіти в сучасному суспільстві. Значна увага приділяється питанню трансформаційних змін в освіті, переведенню їі на інноваційну основу, тобто врахуванню в процесі формування особистості таких інноваційних елементів, які б дозволили забезпечити відповідний рівень конкурентоспроможності освіти у світовому просторі.
Тому саме ці моменти повинні закладатися у фундамент концептуального осмислення особливостей освітянської політики та освітніх технологій сучасності. Сприяти цій справі - першочергове завдання сучасної соціології освіти, на передній план якої виходить аналіз можливостей освіти у процесі формування сучасної особистості, пошук та аналіз методологічних підходів, які найкраще відображають актуальні завдання, що стоять перед освітою. 
У соціології освіти напрацьовано багато різних концептуальних підходів до визначення структурних, процесуальних, функціональних характеристик освіти, і всі вони мають певні різночитання. Це пов'язано з тим, що освіта $€$ предметом аналізу різних галузей наукового знання та вплетена у тканину багатьох соціальних інститутів.

Аналіз досліджень та публікацій. Сучасний рівень дослідження соціології, пов'язаний з проблемами освіти, спирається на соціологічні ідеї М. Вебера, Дж. Дьюї, Е. Дюркгейма, Д. Мангейма, Л. Уорда, Т. Парсонса і на більш пізні концептуальні ідеї зарубіжних і вітчизняних учених.

Дослідження сучасних західних соціологів, серед яких Б. Бернстайн, М. Янг, Н. Луман, М. Арчер та інші, розкривають методологічно значущі напрями у вивченні освіти, доповнюють галузь новим категоріально-понятійним апаратом, розширюють розуміння об'єкта і предмета соціології освіти.

Серед українських соціологів також визначені актуальні питання методології освіти, її інноваційного розвитку, окреслені нові стратегічні завдання сучасної освіти. Так, дослідження В. Астахової, О. Навроцького, Є. Подольської, В. Чепак, І. Нечитайло та російських соціологів В. Нечаєва, Ф. Філіпова та інших спонукають до більш глибокого розуміння змін, що відбуваються в сучасній освіті, та подальшого її вивчення.

Для аналізу освіти продуктивними є компетентнісний, соціокультурний, соціально-реконструкціоністський підходи. Кожен з цих підходів мають свої особливості та переваги. Так, компетентнісний підхід спрямований на комплексне освоєння знань і засобів практичної діяльності, які забезпечують успішне функціонування людини в ключових сферах життєдіяльності в інтересах як її самої, так і суспільства, держави. Соціокультурний підхід до вивчення освіти в спрощеному розумінні передбачає аналіз особливостей відтворювання культури в суспільстві, роль освіти в закріпленні і розповсюдженні культурних інновацій. Соціально-реконструкціоністський підхід спрямований на формування фахівців для суспільства, що постійно трансформується.

Постановка завдання. Мета статті полягає в аналізі соціокомунікативного підходу як методологічної основи у вивченні освіти та його реалізації в сучасних освітніхпрактиках.

Виклад основного матеріалу дослідження. Спробуємо сформулювати основні положення цього підходу. В.Я. Нечаєв стверджує, що, якщо до аналізу освіти підходити з позицій символічного інтеракціонізму, соціолінгвістики й інших сучасних напрямів соціальної думки, то його можна розглядати за допомогою соціокоду - поняття, що пояснює, як здійснюється трансляція накопиченого досвіду в історичному контексті (без чого освіту осмислити просто неможливо). Оскільки соціокод існує в різних формах, освіта на кожному новому етапі свого розвитку послідовно набуває різних форм (наприклад, на зміну інституту духовного наставництва приходить школа з полідисциплінарним навчанням) [4].

Чому ж такий підхід називається соціокомунікативним (акцент на другу частину слова)? Тому що перехід від одного етапу розвитку освіти до іншого відбувається кожного разу через нові засоби комунікації та інформаційної взаємодії (мова, письмовий текст, інформація як засіб комунікації). В нашому дослідженні ми намагаємося проаналізувати ті комунікації, завдяки яким стає можливою передача знань, умінь та навичок в сучасній освіті, що сприяє формуванню соціокоду.

Для більш глибокого розуміння та аналізу освіти в контексті соціокомунікативного підходу зупинимося детальніше на основних поняттях. У системі освіти формування знань, умінь та навичок можливе через процес кодування, який характеризується як символічна мова, за допомогою якої відбувається кодифікування ії̈ учасників. Поняття «кодифікувати» введено П. Бурд'є, воно означає - одночасно надавати форму і дотримуватись формальностей [1, с.121].

Таким чином, педагогічна практика реалізує модель освіти і сприяє підтримці «символічного порядку». Так, наприклад, самі цінності не міняються, трансформуються інтереси, оскільки вони визначають цілі і залежать від змін навколишнього середовища. Проте цінності, закодовані в системі освіти, коректують вибір засобів для досягнення мети.

В освіті педагогіка транслює у вигляді коду певний набір цінностей і норм. Якщо модель освіти відповідає реальним інтересам і потребам, цей набір цінностей і норм слугує консервативним механізмом відтворювання суспільства. Проте, якби інститут освіти не мав консервативної звички зберігати (кодувати) свою прихильність до знань і академічних цінностей, ситуативно-тимчасові потреби суспільства поруйнували б і систему освіти, і саме суспільство.

Кодування - це символічна мова, властива будь-якій системі, у тому числі й індивіду, який завдяки оволодінню певною сумою капіталів (соціального, культурного і економічного) також бере участь у соціумі як певна система. А те, що є внутрішнім кодом індивіда, його реакцією у відповідь на кодування ззовні, характеризується поняттям «соціокод» [7].

Соціокод створюється індивідом на підставі діючих у суспільстві ролей, спираючись на потенціал капіталів навколишнього середовища. Освіта виступає середовищем і аре- 
ною для освоєння різних форм капіталу і вироблення індивідом власного соціокоду.

Поняття кодифікування П'єр Бурд'є розкриває через взаємини практики і освіти. Він виокремлює в освітньому процесі формальну (видиму) педагогіку, називаючи її академізмом і відділяючи її від природного практичного знання. На його думку, досконале, тобто повністю практичне володіння знаннями, перестало існувати щойно хтось замислився над тим, чи можна його опанувати, щойно з'явився задум заснувати правильну практику на правилах, виділених з метою їхньої передачі (так вчиняє будь-який академізм) з практики колишніх часів і з її продуктів [2, с. 202].

Таким чином, процес кодифікування в освіті будується на рівні видимої (формальної) і невидимої (неформальної) педагогіки, захоплюючи весь простір соціуму. Отже, освіту ми розглядаємо як сукупність всіх ролей. Тут можна зупинитися на дослідженнях Б. Бернстайна, який довів, що педагогічні практики можуть бути видимі та невидимі. В першому разі межі системи мають суворий характер, вони належать до формальної педагогіки. В другому разі межі всередині системи визначені слабо, вони належать до неформальних форм освіти [8, с. 59-72].

Іншою підставою для затвердження того, що освіта вбирає в себе всі соціальні ролі суспільства, служать роботи Міхаеля Янга, який також розглядав освіту як соціокультурний процес, не обмежений системою формальної педагогіки. Звичне положення, що формальна педагогіка (або «видима», за Бернстайном, чи «академізм», за Бурд'є) і формальна система освіти контрольовані і схвалені урядом і вони $\epsilon$ єдиною легальною структурою, сьогодні вже не працює. Як відомо, процеси глобалізації розмивають державні межі, у тому числі і в освіті. Є корпоративні університети, які будують свої навчальні плани не на принципах цінностей уряду, а на принципах цінностей корпорації (виробництва, бізнесу) [9].

На думку Н. Лумана, кожна система має свій код, який відділяє одну систему від іншої [3]. Таким чином, межі формальної і неформальної педагогіки (або видимої і невидимої) визначаються кодом, який унікальний за своїм наочно-сутнісним змістом для кожної з систем педагогічної практики. Згідно з теорією систем Н. Лумана, зв'язок між системами здійснюється через інтерпретацію цих кодів (осмислення чужого коду на поняттях рідного коду). Наприклад, якщо інституціоналізація знань у видимій педагогіці відбувається на принципі державності, а в невидимій - на принципі корпорації, то знання в кожному разі трактуються по-своєму. Для видимої педагогіки - це знання, що забезпечують прихильність діючої державної ідеології і зберігають рівень еконо- мічного процвітання цієї країни; для невидимої педагогіки - це знання, що визначають ідеологію та економічне процвітання окремо взятої корпорації, соціальної групи і будь-якої іншої структури недержавної освіти.

В. Нечаєв, аналізуючи історичні форми передачі знань в контексті соціокомунікативного підходу, вказує на те, що основною функцією сучасної школи є дисциплінарне навчання, яке поєднує в собі професійну підготовку та виховання, тобто те, що властиво системі освіти генетично, за що вона несе відповідальність як інститут сучасної цивілізації. Водночас школа виконує й інші функції інтеграції, селекції, мобільності, соціального контролю та інші.

При цьому неадекватне розширення зони відповідальності школи, нехай навіть з гуманними намірами, спричиняє собою втрату провідних орієнтирів, розмиває її призначення. Прикладом тому служить висунення перед школою таких суперзавдань, як «виховання гармонійно розвиненої особистості» або «розкриття здібностей людини». Поза сумнівом, це дуже важливі цілі, але вони підтримують загальний фон дії усього соціокультурного простору соціалізації людини і $€$ необхідною передумовою організації всього освітнього процесу в школі, але ніяк не заміщають роль основної функції школи [4, с. 90].

Водночас швидкоплинний розвиток сучасного суспільства задає імпульс і для змін в освіті. Це актуалізує необхідність у постійній взаємодії суспільства з освітою. «Зміни в суспільстві через зміни в освіті» - так українська дослідниця І. Нечитайло бачить вирішення протиріч, які існують в освіті та можуть стати поштовхом до позитивних змін в суспільстві [5]. Досліджуючи освітні практики, І. Нечитайло наголошує на взаємовпливі формальної та неформальної педагогіки, актуалізуючи роль неформальної або невидимої педагогіки в освітньому процесі, розкриваючи це питання через поняття «скрита навчальна програма». Дослідниця звертає увагу на те, що процес освіти та його результати - це не тільки отримання знань, умінь, навичок, компетенцій з відповідних дисциплін, за якими навчаються згідно з офіційною освітньою програмою. На цей час освіта, як і інші соціальні інститути, може транслювати неявне знання. Так, для багатьох навчальний заклад стає «другою домівкою», де не тільки навчають, але й виховують, формують цінності, захищають, «стандартизують» та контролюють наші дії, життя, навіть якщо ми знаходимося поза освітнім закладом. У зв'язку з цим у навчальному закладі багатьом аспектам поведінки індивіди навчаються на неформальному рівні. Навчальні заклади, вчителі, викладачі можуть розглядатися як «розповсюджувачі» досвіду, 
який не є обов'язковим, який не прописаний у формальних освітніх документах. Отже, $€$ набір цінностей, установок та принципів, які транслюються поза офіційною програмою, що дає підстави для виокремлення явної (офіційної, формальної) та неявної (неофіційної, неформальної) форм освіти [5, с. 180].

Отже, в реальній освітній практиці до формальної педагогіки в системі освіти, зокрема вищої школи, можемо віднести реалізацію, наприклад, освітньо-професійних програм та їх чіткого дотримання, як з боку професорсько-викладацького складу, так і з боку здобувачів (в іншому разі отримання диплому про вищу освіту неможливе). Що ж до неформальної педагогіки, то тут можемо зазначити про реалізацію таких форм освітніх практик, як культурно-дозвіллєві заходи, участь у наукових гуртках, спілкування з одногрупниками, викладацьким складом тощо). Отже, в контексті соціокомунікативного підходу функціонування повноцінного освітнього процесу можливе з урахуванням реалізації як формальної педагогіки (видимої, офіційної), так і неформальної педагогіки (невидимої, неофіційної).

Повертаючисьдопоняття «соціокод», зазначимо, що формування соціокоду відбувається під впливом формальної (видимої) і неформальної (невидимої) педагогіки. Якщо код $€$ межею системи, то соціокод - це регулятор системи. Через соціокод людина ідентифікує себе з певним соціальним прошарком, певним інтелектуальним рівнем, з певними світоглядними позиціями, культурами тощо. Тут виявляється культуротворча сутність освіти [7].

Ухвалені людиною в процесі освіти та виховання цінності і норми відображають її інтереси і складають їі соціокод. Соціокод не можна дати, він вирощується в особистості нею самою в тому середовищі, в якому вона знаходиться; соціокод є своєрідним віддзеркаленням соціальних, в тому числі і освітніх практик. Унікальність кожного соціокоду індивіда забезпечує трансформацію соціальних практик, привносячи в очікувані ролі нові компоненти. Виникнення нових соціальних практик змінює «інституціоналізовану нормативну культуру», а разом з нею і структуру соціальних систем, оскільки вона «загалом складається з інституціоналізованих стандартів нормативної культури» [6].

Висновки. Отже, за будь-якої суспільної формації в конкретний час освіта, відповідаючи на її запити, обов'язково буде відтворювати цінності, норми і формувати соціокод індивіда. В цьому виявляється унікальність і універсальність системи освіти: універсальність як форми і унікальність з наочносутнісного наповнення [7, с. 97]. Універсальність в системі освіти - це та константа, яка дозволяє критично осмислювати і реальність, і саму науку. На підставі узагальнень, що відображають універсальність освіти, педагогічна практика кодифікує все різноманіття соціальних ролей. Якщо кодифікуючий комплекс, що виявляе наочно-сутнісне наповнення освіти, відповідає вимогам часу і суспільства, то інститут освіти $€$ могутнім джерелом розвитку суспільства.

Отже, соціокомунікативний підхід демонструє свою методологічну значущість у поясненні механізмів трансляції знань, умінь, навичок, компетенцій як в історичному контексті, так і в сучасних освітніх практиках. Акцентуючи увагу на освітніх практиках сучасної школи, цей підхід дає можливість аналізувати все різноманіття соціальних ролей, від формальної до неформальної педагогіки.

\section{ЛITEPATУРA:}

1. Бурдье П. Начала / пер. с фрр. Н.А. Шматко. Москва : Socio-Logos, 1994. 288 c.

2. Бурдье П. Практический смысл / Пер. с фрр. А.Т. Бикбов, К.Д. Вознесенская, С.Н. Зенкин, Н.А. Шматко ; Отв. ред. пер. и послесл. Н.А. Шматко. Санкт-Петербург : Алетейя, 2001. 562 с.

3. Луман Н. Социальные системы. Очерк общей теории / пер. с нем. И.Д. Газиева. Под редакцией Н.А. Головина. Санкт-Петербург : Наука, 2007. 648 c. URL: http://yanko.lib.ru/books/sociology/lumansoc+sist_ocherk-2007-1984-a.htm (дата звернення: 04.05.2020).

4. Нечаев В.Я. Новые подходы в социологии образования. Социологические исследования. 1999. № 11. C. 84-91.

5. Нечитайло И.С. Изменение общества через изменение образования: иллюзия или реальность : монограсрия. Харьков : ХГУ «НУА», 2015. 552 с.

6. Парсонс Т. Система современных обществ/пер. с англ. Л.А. Седова, А.Д. Ковалева. Москва : Аспект Пресс, 1998. 266 с.

7. Шаронова С.А. Универсальные константы института образования - механизм воспроизводства общества : монографрия. Москва : Изд-во РУДН, 2004. 357 c.

8. Bernstein B. Class and Pedagogies: Visible and Invisible / Halsey A.H., Lauder H., Brown Ph., Wells A.S. (eds.). Education: Culture, Economy, Society. New York : Oxford Univesity Press, 1997. P. 59-79.

9. Youn Michael F.D. Sociology of Education as Critical Theory. New York, 1990. 